\title{
Topographic and geomorphologic controls on the distribution of vegetation formations in Elephant Point (Livingston Island, Maritime Antarctica)
}

\author{
Jesús Ruiz-Fernández ${ }^{\mathrm{a}, *}$, Marc Oliva ${ }^{\mathrm{b}}$, Cristina García-Hernández ${ }^{\mathrm{a}}$ \\ a Department of Geography, University of Oviedo, Teniente Alfonso Martínez s/n, 33011 Oviedo, Spain \\ ${ }^{\mathrm{b}}$ Centre for Geographical Studies - Institute of Geography and Spatial Planning, Universidade de Lisboa, Rua Branca Edmée Marques - Edificio do IGOT, $1600-276$ Lisbon, Portugal
}

\section{H I G H L I G H T S}

- We identified four different vegetable formations in Elephant Point, Antarctica.

- These formations are mainly distributed in bedrock plateaus and raised beaches.

- Only $10.5 \%$ of the peninsular area is vegetated.

- These formations have barely colonised the areas deglaciated since 1956.

- Time passed since the deglaciation is a key factor to explain vegetable colonisation.

\section{G R A P H I C A L A B S T R A C T}

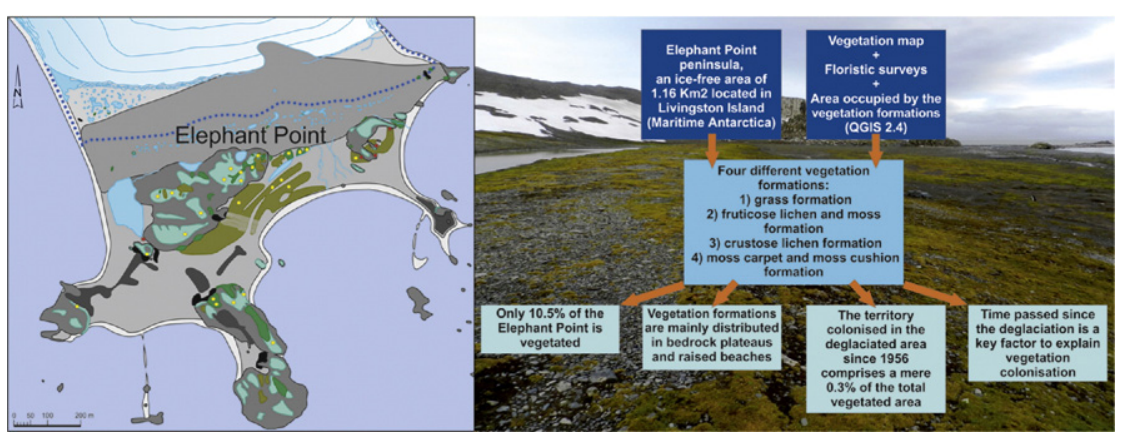

\section{A R T I C L E I N F O}

\section{Article history:}

Received 2 November 2016

Received in revised form 17 February 2017

Accepted 18 February 2017

Available online 24 February 2017

Editor: D. Barcelo

\section{Keywords:}

Elephant Point

Antarctica

Vegetation

Tundra

Geomorphology

\begin{abstract}
A B S T R A C T
This article focuses on the spatial distribution of vegetation formations in Elephant Point, an ice-free area of $1.16 \mathrm{~km}^{2}$ located in Livingston Island (South Shetland Islands, Antarctica). Fieldwork carried out in January 2014 consisted of floristic surveys and designation of a vegetation map. We have examined these data in a GIS environment together with topographical and geomorphological features existing in the peninsula in order to infer the factors controlling vegetation distribution. This has allowed quantifying the total area covered by the four different vegetation formations distributed across the peninsula, proliferating mainly on bedrock plateaus and Holocene raised beaches. Grass formation is essentially composed of Deschampsia antarctica, distributed almost exclusively on raised beaches, and covering $4.1 \%$ of the ice-free surface. The remaining three formations are fundamentally composed of cryptogam species. The first of which is fruticose lichen and moss formation, present on high bedrock plateaus and principally formed by lichens such as Usnea aurantiaco-atra. The next is the crustose lichen formation, spreading on bedrock plateaus near the coast populated by bird colonies. In this case, ornitocoprophilous lichens such as Caloplaca regalis, Xanthoria elegans and Haematomma erythromma are predominant. Together, both formations have colonised $5.1 \%$ of the peninsula. The last variety, moss carpet and moss cushion formation, occupies $1.4 \%$ of the deglaciated surface, spreading primarily in flooded areas, stabilised talus slopes, and bedrock plateaus as well. Therefore, the total surface colonised by vegetation is 12.2 ha, which comprises $10.5 \%$ of the peninsula. Due to the retreat of the Rotch Dome glacier, 20.1 ha remain ice-free since 1956 (17.3\% of the deglaciated area). Ever since, even though the Antarctic
\end{abstract}

\footnotetext{
* Corresponding author at: Department of Geography, University of Oviedo, C/Teniente Alfonso Martínez s/n, 33011 Oviedo, Spain.

E-mail address: ruizjesus@uniovi.es (J. Ruiz-Fernández).
} 
Peninsula has registered one of the most significant temperature rises on Earth, vegetation has only colonised 0.04 ha of this new space, which merely represents $0.3 \%$ of the vegetated area in Elephant Point.

(C) 2017 Elsevier B.V. All rights reserved.

\section{Introduction}

The Antarctic continent is almost completely covered by glacial ice. Ice-free areas account for a mere $0.4 \%$ of its area, and they generally correspond to small coastal stretches. Most of these deglaciated coastlines are located around the Antarctic Peninsula (AP) and adjacent islands, where the average annual temperatures are marginally below $0{ }^{\circ} \mathrm{C}$. Most precisely, the ice-free coastlines of the AP encompass the areas exhibiting the highest biodiversity levels in Antarctica (Toro et al., 2007).

The progressive glacier retreat in the AP began after the Last Glacial Maximum (Ingólfsson et al., 1998; Ó Cofaigh et al., 2014), and continued during the Holocene (Bentley et al., 2009), as the climate variability occurred in the last millennia caused substantial changes in terrestrial ecosystems in these ice-free areas. This glacier retreat has increased in the AP's coastal environments during the last decades (Oliva and Ruiz-Fernández, 2015, 2016), as a response to the warming detected since the mid-20th century (Turner et al., 2005; Oliva et al., 2017). Besides, it has fostered the creation of new exposed terrestrial surfaces, and the expansion of those that already existed, and which generally provide habitat for many birds and diverse pinniped species.

Sparse vegetation, essentially composed of moss and lichens, has progressively developed in the ice-free spaces of recent creation, forming an open tundra. There are numerous studies on various vegetation species present in these sites and their strategies for expanding and propagating (Lewis, 1995; Cuba et al., 2005; Zúñiga et al., 2009; Torres-Mellado et al., 2011; Vera, 2011; Casanova-Katny and Cavieres, 2012), their reproductive capacity (Vera et al., 2013), and other diverse biological and ecological aspects. However, few works focus on the characterisation, distribution and mapping of these vegetation communities, namely, those relying on a more geographical perspective (e.g. Vera, 2011; Victoria et al., 2013). Methodologies for vegetation mapping can vary greatly depending on the size and characteristics of the study area, as well as on the study objectives. When study areas are relatively small (such as the area in this research), the use of field work to generate the cartography is a common approach (e.g. Victoria et al., 2013), whereas in areas of greater extension the use of remote sensing imagery is widespread (Harvey and Hill, 2001; Kokaly et al., 2003). In this case it is necessary to identify the correlations of the different vegetation types with the discernible spectral characteristics of the remote sensing imagery (Xie et al., 2008).

In this sense, and from a geoecological perspective, scientists have recently proposed the creation of a protected site, designated as Antarctic Specially Protected Area (ASPA) in Elephant Point (Oliva et al., 2016), a small area deglaciated in the latest Holocene on the southeast flank of Livingston Island, in the South Shetland Islands archipelago (SSI). This area comprises a wide variety of landforms and processes characteristic to Maritime Antarctica (Oliva and Ruiz-Fernández, 2016), together with some of the best-preserved archaeological remains left by sealers in the AP (Oliva et al., 2016). Nevertheless, a detailed knowledge of the vegetation, its species and spatial distribution in this small peninsula, has not yet been analysed, and it is of capital importance for the categorisation and subsequent implementation of regulations associated with the designation of ASPA in Elephant Point.

Designed to overcome the current lack of knowledge of the natural system in Elephant Point, this work focuses on the distribution of vegetation and its interrelationships with the present and past geomorphological dynamics in the above-mentioned peninsula. Its development will provide solutions to several specific objectives:
1. Identifying, characterising and mapping the vegetation formations present in the peninsula, as well as measuring their spatial extension and their relation with other existing geomorphological units.

2. Discussing the factors explaining their characteristics and geographical distribution.

3. Evaluating the vegetation colonisation occurred since the recent deglaciation as a response to the warming registered during the second half of the 20th century in the AP (Turner et al., 2005).

\section{Study area}

The Elephant Point peninsula $\left(62^{\circ} 40^{\prime} 53^{\prime \prime} \mathrm{S}-62^{\circ} 41^{\prime} 34^{\prime \prime} \mathrm{S}\right.$ latitude, $60^{\circ} 52^{\prime} 21^{\prime \prime} \mathrm{W}-60^{\circ} 50^{\prime} 48^{\prime \prime} \mathrm{W}$ longitude) is situated in the southwest side of Livingston Island, which is the second largest Island in the SSI archipelago. This archipelago is located $120-130 \mathrm{~km}$ to the northwest of the AP, separated from it by the Bransfield Strait (Fig. 1). Like the rest of the SSI, Livingston Island is mainly covered by glaciers. From a topographic point of view the least significant areas of this island consist of glacial domes with smooth slopes, and their fronts generally reach the sea. Conversely, mountain glaciers have been formed on the peaks and in the more mountainous areas of the island.

The glacial retreat occurred during the Holocene has likewise generated ice-free areas that, on average, constitute $10 \%$ of the archipelago area (Serrano, 2003), showing important variations among islands: from $\sim 57 \%$ in the volcanic Deception Island to $\sim 10 \%$ of the surface in King George and Livingston (Serrano, 2008). The deglaciated areas present dissimilar dimensions: from the $\sim 60 \mathrm{~km}^{2}$ of Byers (Livingston), to areas with less than $1 \mathrm{~km}^{2}$ on the sides of the islands. The Elephant Point peninsula is among the smaller extensions, displaying $1.16 \mathrm{~km}^{2}$ of ice-free areas. Fig. 1C shows that approximately $17.3 \%$ of the above extension has formed between 1956 and 2010 due to the retreat of the Rotch Dome glacier (Oliva and Ruiz-Fernández, 2015, 2016), as indicated by the dotted line.

The climatic characteristics of the area are those of the northwest extremity of the AP and, by extension, of the SSI. In a station situated in the nearby Byers Peninsula, about $10 \mathrm{~km}$ away from Elephant Point, the average annual temperature at $70 \mathrm{~m}$ asl for the period 2002-2010 was $-2.8^{\circ} \mathrm{C}$, while annual precipitation ranged between 500 and $800 \mathrm{~mm}$ (Bañón et al., 2013). The magnitude and length of low temperatures becomes the main limiting factor for vegetation development, comprising three months a year in which the average temperature is above $0{ }^{\circ} \mathrm{C}$ on average (Serrano, 2003, 2008; Newsham, 2010).

In Elephant Point the deglaciated area is mainly formed by basalt, and the following geomorphological units are distributed in the peninsula: proglacial area, moraine system, bedrock plateaus, raised beaches and present-day beach (Oliva and Ruiz-Fernández, 2016). Each of these units has particular implications with respect to vegetation distribution and wildlife. Periglacial landforms are diverse and abundant. Periglacial processes are very active, especially those connected with the presence of ice in the ground, and the seasonal variation of the active layer (frost shattering, cryoturbation, fast and slow mass movements, etc.). As happens in other recently deglaciated maritime environments in the SSI, permafrost conditions in Elephant Point are widely extended. The evolution of the annual snow cover also has important geomorphological effects, such as the existence of several active pronival ramparts in the area (Oliva and Ruiz-Fernández, 2016).

This peninsula boasts a large concentration of wildlife, mostly circumscribed to the area of marine influence, namely the present-day beach, the five levels of Holocene raised beaches and the surrounding 

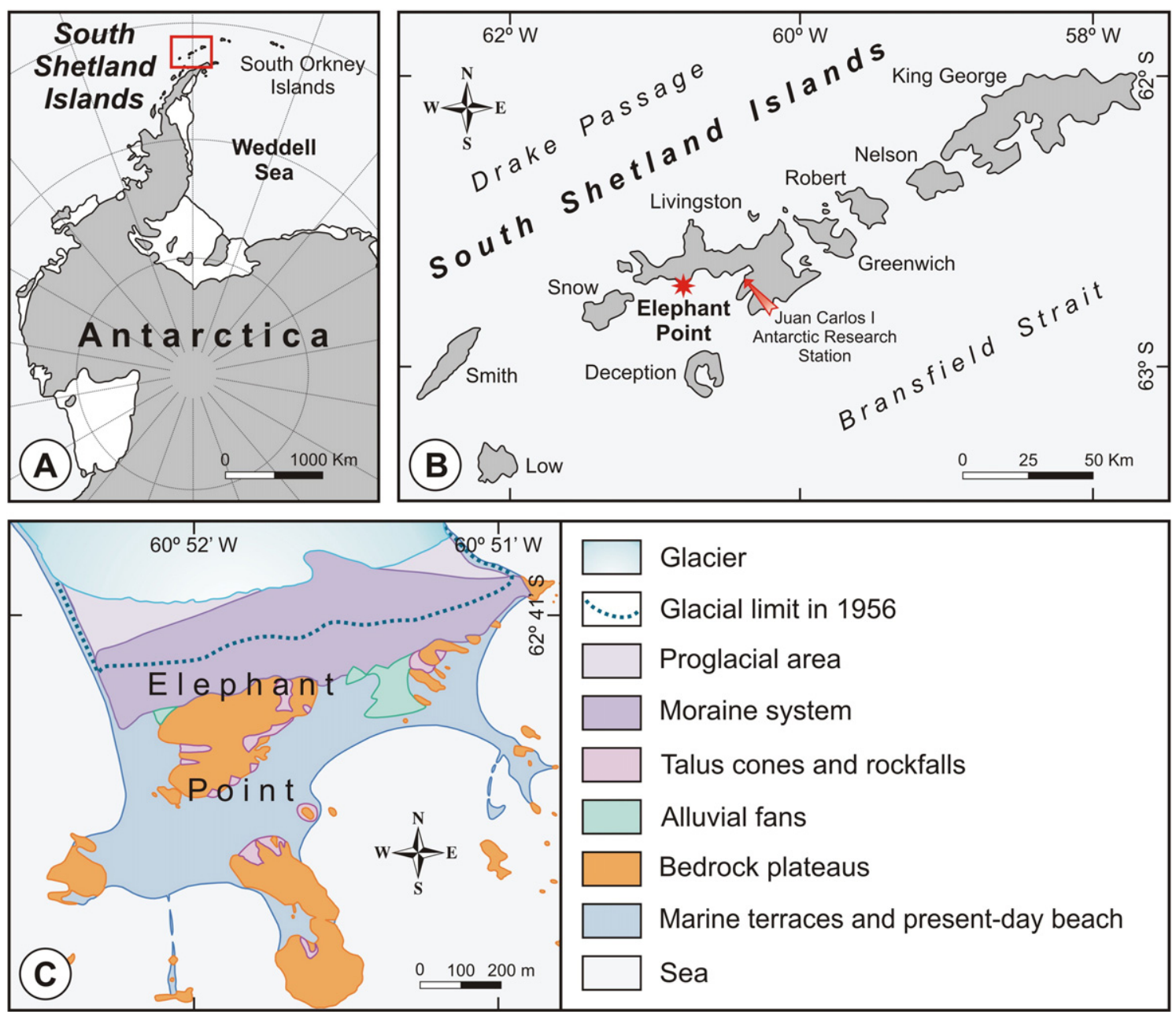

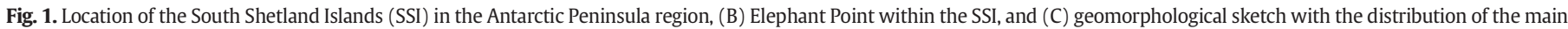
landforms in Elephant Point.

rocky promontories. There are five colonies of gentoo penguins (Pygoscelis papua), seven colonies of elephant seals (Mirounga leonina) and numerous colonies of southern giant petrels (Macronectes giganteus) (Oliva et al., 2016). Conversely, the vegetation cover is integrated by the only two native Antarctic vascular plants: Deschampsia antarctica and Colobanthus quitensis (Zúñiga et al., 2009; Vera, 2011; Casanova-Katny and Cavieres, 2012; Vera et al., 2013), alongside several species of lichens and mosses, forming an open tundra.

Human activity in the area has been very scarce. As happens in the nearby Byers Peninsula, we should note the existence of remains in ancient camps set up by the sealers and whalers that travelled along these coasts between the end of the 18th century and the first decades of the 19th century (Zarankin and Senatore, 2005). However, unlike in Byers, where numerous scientific campaigns have been undertaken in the last decades, there has been practically no scientific activity in Elephant Point, which has favoured its preservation as a pristine ecosystem.

\section{Methods}

This study involves the design of a detailed map of vegetation distribution in the Elephant Point peninsula, based on the fieldwork carried out in January 2014, after a snowy year in the SSI (Fig. 2). For this purpose, systematic transepts were carried out across Elephant Point peninsula. Subsequently, the map was completed through photointerpretation. The cartographic base used is a satellite image from Google Earth in 2010. There is no topographic map of the area. The output of the map has been created with the program CorelDraw 14. It is worth pointing out that the two vegetation formations mainly integrated by lichens are shown together on the map, since one of them, the crustose lichen formation, is generally subdivided into a multitude of sectors which are too small to be shown on this scale. Additionally, 25 floristic surveys in $1 \mathrm{~m}^{2}$ plots have been conducted, and apart from validating the information contained in the map, they have contributed to establish the floristic composition of the identified vegetation formations (Table 1). On the other hand, area calculation has been carried out by means of the QGIS 2.4 software and the geo-referenced image available on the Google Earth web service, using the provided cartography as reference. We have calculated the area covered by each of the geomorphological units referred to in the text (proglacial area, moraine system, bedrock plateaus, raised beaches and present-day beach), the area occupied by each of the vegetation formations identified in each of the geomorphological units, and likewise the area occupied by these vegetation formations in relation to the total area of the Elephant Point peninsula (Tables 2 and 3). The area occupied by the two formations dominated by lichens has been calculated together. Finally, the area deglaciated since 1956 has been computed by comparing the aerial image of 1956 (U.S. Geological Survey; Oliva and Ruiz-Fernández, 2016) with the recent image of 2010 of Google Earth.

\section{Results}

Four different vegetation formations have been identified, distributed on the high bedrock plateaus and the highest four Holocene raised beaches $(+10,+7,+5$ and $+3 \mathrm{~m}$ asl $)$, which are the oldest 


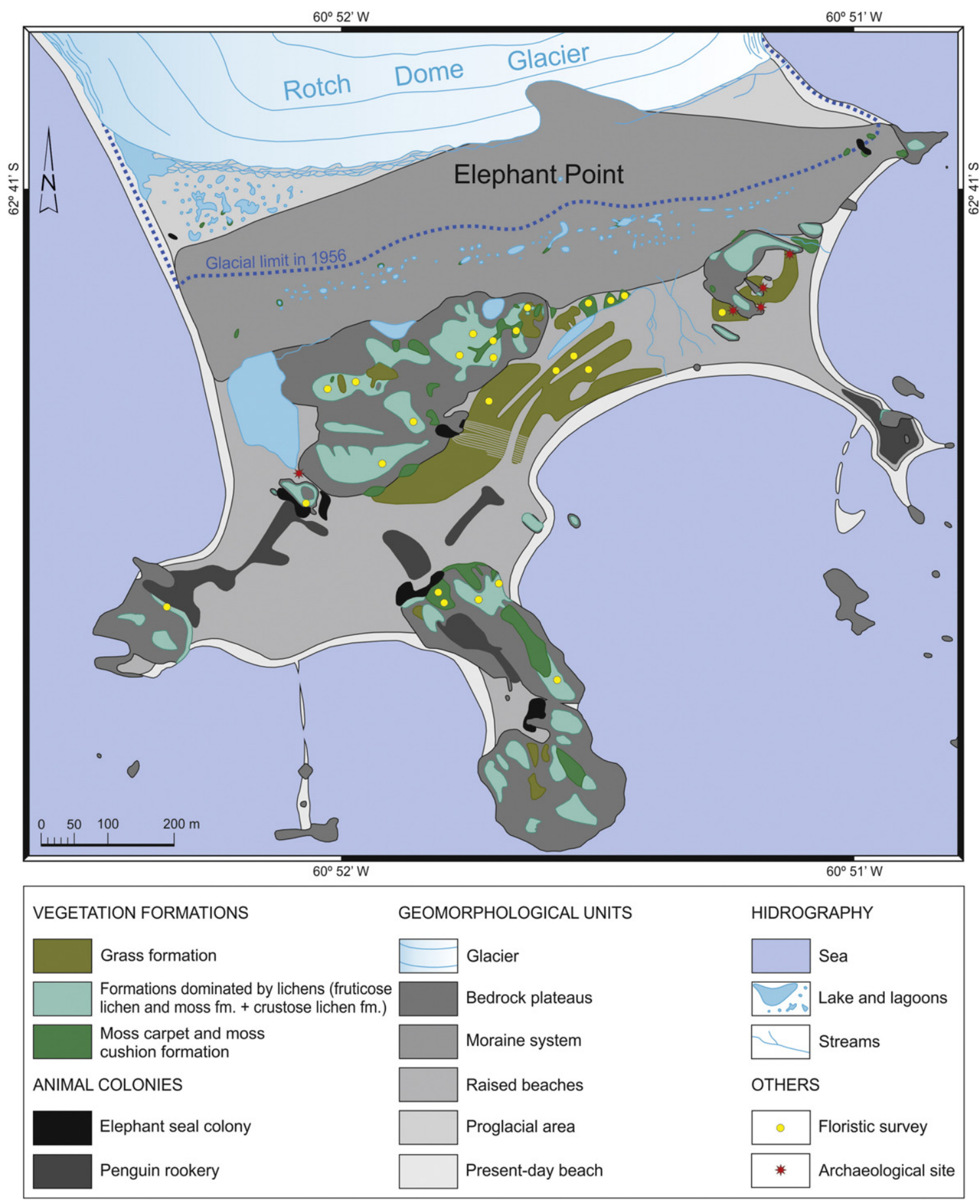

Fig. 2. Vegetation map of Elephant Point peninsula.

topographical units of the peninsula. The vegetation formations identified are: 1) grass formation; 2) fruticose lichen and moss formation; 3 ) crustose lichen formation; 4) moss carpet and moss cushion formation (Fig. 2). Essentially, the first formation is composed of phanerogam plants, whereas the remaining three formations basically consist of cryptogam species.

The remaining recently created terrain in Elephant Point (presentday beach, lowest raised beach, moraine system and proglacial area) are void or nearly void of vegetation. It is worth highlighting the cyanobacterial mats (Phormidium sp.) present in the lagoons formed on some levels of the raised beaches, and the reddish and greenish spots identified in the snow along the edges of the Rotch Dome glacier in the proximity of the coast, and also on the edges of permanent and semi-permanent snowfields. These spots are related to the presence of snow-algae communities (Chlamydomonas sp. and Chloromonas sp.; Remias et al., 2013).

\subsection{Grass formation}

This formation is distributed mainly on the raised beaches located in the southern side of the peninsula, especially on upper levels (Figs. 2, 3 , 4A, B). In these areas soils are deeper and more organic in content than in other environments of Elephant Point, due to the nutrients provided by bird and elephant seal colonies. The grass formation in composed principally of Antarctic hair grass (Deschampsia antarctica) and, to a lesser extent, of Antarctic pearlwort (Colobanthus quitensis). Besides, 
Table 1

Plant and lichen species identified in Elephant Point.

\begin{tabular}{ll} 
Algae & \\
Prasiola crispa (Lightfoot) Kützing. & $\begin{array}{c}\text { Lichenized and lichenicolous fungi } \\
\text { Caloplaca regalis (Vain.) Zahlbr. }\end{array}$ \\
Bryophyta & Haematomma erythroma (Nyl.) Zahlbr. \\
Amblystegiaceae & Himantormia lugubris (Hue) Lamb \\
Sanionia uncinata (Hedw.) Loeske & Lecanora physciella (Darb.) Hertel \\
Warnstorfia laculosa (Müll. Hal.) & Leptogium puberulum Hue \\
Ochyra \& Matteri = Calliergidium & Mastodia tessellata (Hook.f. \& Harv.) \\
austro-stramineum (C. Muell.) & Hook.f. \& Harvey \\
Warnstorfia sarmentosa (Wahlenb.) & Ochrolechia frigida (Sw.) Lynge \\
Hedenäs = Calliergon sarmentosum & Peltigera rufescens (Weiss) Humb. \\
(Wahlenb.) Kindb. genannt. & Placopsis contortuplicata Lamb \\
& Ramalina terebrata Hook et Tayl. \\
Andreaeaceae & Rhizocarpon geographicum (L.) DC. \\
Andreaea depressinervis Card. & Umbilicaria antarctica Frey \& I. M. Lamb \\
Andreaea gainii Card. & Umbilicaria decussata (Vill.) Zahlbr. \\
& Usnea antarctica Du Rietz \\
Bryaceae & Usnea aurantiaco-atra (Jacq.) Bory \\
Pohlia nutans (Hedw.) Lindb. & Xanthoria candelaria (L.) Th. Fr. \\
& Xanthoria elegans (Link.) Th. Fr. \\
Polytrichaceae & \\
Polytrichastrum alpinum (Hedw.) G.L. & Marchantiophyta \\
Smith & Cephaloziellaceae \\
Polytrichum piliferum Hedwig & Cephaloziella varians (Gottsche) Steph. \\
Chlorophyta & \\
Chlamydomonas sp. & Phanerogams \\
Chloromonas sp. & Colobanthus quitensis (Kunth) Bartl \\
Cyanophyta & Deschampsia antarctica Desv. \\
Phormidium sp. & \\
& \\
& \\
\hline & \\
&
\end{tabular}

several mosses such as Polytrichastrum alpinum and Polytrichum piliferum are also present. Furthermore, basaltic bedrock plateaus display grass formation stands dominated by Deschampsia antarctica as well (Table 1).

\subsection{Fruticose lichen and moss formation}

This vegetation formation widely spreads on the high bedrock plateaus, and on smaller rocky surfaces present on raised beaches (Figs. 2, 3, 4C, D). It covers not only the rocky outcrops in situ, but also stable superficial formations and soils not subject to intense cryoturbation. This formation is generally composed of a group of fruticose lichens such as Usnea aurantiaco-atra, Usnea antarctica, Ramalina terebrata and Himantormia lugubris. However, the Usnea aurantiacoatra clearly predominates over the rest and is widely distributed in the peninsula. Our floristic surveys have likewise confirmed the presence of foliose lichens such as Peltigera rufescens, Umbilicaria antarctica, Umbilicaria decussata and Leptogium puberulum, and crustose lichens such as Rhizocarpon geographicum. Besides, mosses such as Polytrichastrum alpinum and Andreae gainii usually accompany these lichen species (Table 1).

\subsection{Crustose lichen formation}

The crustose lichen formation spreads on platforms and rocky areas exposed to the sea, harbouring numerous bird colonies (Figs. 3, 4E, F). This vegetation formation is fragmented into a multitude of small patches. Sometimes these lichens can be found on the vertical walls of basaltic rocky outcrops, as seen on the east flank of the southernmost bedrock plateau in the peninsula. Ornithocoprophilous lichens such as Caloplaca regalis, Xanthoria elegans and Haematomma erythromma predominate here. The latter species proliferates chiefly in the proximity of petrel perches and nests. This type of tundra also holds various other lichens preferentially such as Xanthoria candelaria, Lecanora physciella, Rhizocarpon geographicum, Ochrolechia frigida and Placopsis contortuplicata (Table 1). The majority of the species are crustose lichens, but there are some fruticose lichens (e.g. Xanthoria elegans, Xanthoria candelaria) and even foliose lichens (Mastodia tessellata).

\subsection{Moss carpet and moss cushion formation}

Water saturated areas (alluvial fans, lagoon edges, high and intermediate raised beaches, etc.) are covered with bryophytes such as Sanionia uncinata, Warnstorfia laculosa and Warnstorfia sarmentosa, which occasionally generate dense carpets of metric or decametric size, as is the case of some alluvial fans located at the foot of the southern side of the moraine system crossing the peninsula from east to west (Figs. 2, 3, 4G, H, Table 1). The liverwort Cephaloziella varians is also present, mainly in meltwater grooves, but also in drier habitats such as rock fissures. Mosses are also present on stabilised talus slopes and rocky outcrops, as observed in the southernmost bedrock plateau of Elephant Point. The floristic surveys conducted in better-drained sites have confirmed the predominance of species such as Andreaea gainii, Andreaea depressinervis, Pohlia nutans, Polytrichastrum alpinum and Polytrichum piliferum. Likewise, the existence of ornithogenic soils fosters the development of moss cushions, as observed in the vicinity of a colony of southern giant petrels, located in the western extremity of the largest bedrock plateau in the study area. In these relatively humid sites densely populated by bird colonies we can find some specimens of foliose green algae Prasiola crispa.

\subsection{Spatial distribution of vegetation}

Vegetation occupies 12.2 ha of the ice-free area of the peninsula, which represents $10.5 \%$ of its total surface (Table 2 ). Bedrock plateaus are the most widely colonised geomorphological unit (Figs. 2 and 5A). In them 7.5 ha are covered with vegetation, equivalent to $37.5 \%$ of its area (Table 2). The second type of geomorphological unit most widely vegetated is represented by marine terraces, where vegetation occupies $15.9 \%$ of their surface ( 4.6 ha) (Fig. $5 \mathrm{~A}$ ). Only $0.4 \%$ of the surface of the moraine system and $0.2 \%$ of the proglacial area are colonised. The present-day beach is completely void of vegetation. Since 1956 the Rotch Dome glacier has undergone a substantial retreat, uncovering an area of 20.1 ha, which represents $17.3 \%$ of the current ice-free surface forming the Elephant Point peninsula. According to our calculations,

Table 2

Absolute and relative vegetated surface in the ice-free area of Elephant Point, depending on the type of vegetation formation and geomorphological unit.

\begin{tabular}{|c|c|c|c|c|c|c|c|c|}
\hline \multirow[t]{2}{*}{ Geomorphological unit } & \multicolumn{2}{|c|}{ Grass formation } & \multicolumn{2}{|c|}{$\begin{array}{l}\text { Formations dominated } \\
\text { by lichens }\end{array}$} & \multicolumn{2}{|c|}{ Moss formation } & \multicolumn{2}{|c|}{$\begin{array}{l}\text { Total vegetated surface } \\
\text { area }\end{array}$} \\
\hline & (ha) & $\%$ & (ha) & $\%$ & (ha) & $\%$ & (ha) & $\%$ \\
\hline Moraine system & 0.00 & 0.0 & 0.00 & 0.0 & 0.09 & 0.4 & 0.09 & 0.4 \\
\hline Raised beaches & 4.29 & 14.7 & 0.00 & 0.0 & 0.35 & 1.2 & 4.63 & 15.9 \\
\hline Bedrock plateaus & 0.44 & 2.2 & 5.90 & 29.6 & 1.15 & 5.8 & 7.49 & 37.5 \\
\hline Proglacial area & 0.00 & 0.0 & 0.00 & 0.0 & 0.02 & 0.2 & 0.02 & 0.2 \\
\hline Present-day beach & 0.0 & 0.0 & 0.0 & 0.0 & 0.0 & 0.0 & 0.0 & 0.0 \\
\hline Total ice-free area & 4.72 & 4.1 & 5.90 & 5.1 & 1.60 & 1.4 & 12.23 & 10.5 \\
\hline
\end{tabular}


Table 3

Percentage of the total area colonised by each vegetation formation in each geomorphological unit.

\begin{tabular}{llll}
\hline $\begin{array}{l}\text { Geomorphological } \\
\text { unit }\end{array}$ & $\begin{array}{l}\text { Grass } \\
\text { formation (\%) }\end{array}$ & $\begin{array}{l}\text { Formations dominated by } \\
\text { lichens (\%) }\end{array}$ & $\begin{array}{l}\text { Moss } \\
\text { formation (\%) }\end{array}$ \\
\hline Moraine system & 0.0 & 0.0 & 5.5 \\
Raised beaches & 90.8 & 0.0 & 21.6 \\
Bedrock plateaus & 9.2 & 100.0 & 72.0 \\
Proglacial area & 0.0 & 0.0 & 0.9 \\
Present-day beach & 0.0 & 0.0 & 0.0 \\
Total & 100.0 & 100.0 & 100.0 \\
\hline
\end{tabular}

the vegetation colonising this new ice-free terrain during this period covers 0.04 ha, which only represents $0.3 \%$ of the total vegetated surface of the peninsula (Figs. 2 and 5B).

The vegetation in both the proglacial area and moraine system is exclusively composed of mosses. Lichen formations are predominant on the bedrock plateaus ( 5.9 ha), where they occupy $29.6 \%$ of its total area, followed by moss formation (1.2 ha), which in this case occupies $5.8 \%$ (Table 2). Grass formation predominates on raised beaches, covering $14.7 \%$ of this geomorphological unit, followed by moss formation ( 0.4 ha, $1.2 \%$ of its total extension).

The most widespread vegetation formations in the ice-free area are fruticose lichen and moss formation, and crustose lichen formation, dominated by lichens in both cases. The area occupied by these formations has been mapped and measured together. In total they cover 5.9 ha, which corresponds to $5.1 \%$ of the peninsular area (Table 2 ). This colonisation, however, is restricted to bedrock plateaus, where we can find $100 \%$ of these vegetation formations in Elephant Point (Table 3; Fig. 5A). The second largest vegetation formation is grass formation ( $4.7 \mathrm{ha}$ ), which occupies $4.1 \%$ of the ice-free surface. It is located primarily on raised beaches, representing $90.8 \%$ of the area colonised by this formation (Table 3; Fig. 5A). Lastly, moss formation is the least widespread, occupying 1.6 ha, which represents $1.4 \%$ of the ice-free surface of the peninsula. This vegetation formation is primarily located on the bedrock plateaus, where we can observe $72 \%$ of its total area, and on marine terraces, where its presence reaches $21.6 \%$ (Table 3 ). While moss formation is the only vegetation present in the moraine system and proglacial area, these two geomorphological units merely concentrate $5.5 \%$ and $0.9 \%$, respectively, of the area covered by this vegetation formation.

\section{Discussion}

The distribution of vegetation formations in Elephant Point shows a spatial pattern connected with the progressive deglaciation of the peninsula during the Holocene (Oliva and Ruiz-Fernández, 2016). Vegetation colonisation, as happens in other deglaciated areas of the SSI, requires a time lapse that may fluctuate depending on topography, prevailing geomorphological processes, and vegetation species involved (Sancho and Valladares, 1993).

Field observations have helped to identify four vegetation formations: 1) grass formation; 2) fruticose lichen and moss formation; 3) crustose lichen formation; 4) moss carpet and moss cushion formation. Firstly, combined formations dominated by lichens have managed to colonise $5.1 \%$ of the ice-free area, thus becoming the most abundant vegetation type in Elephant Point. In fact, various investigations have demonstrated that lichens are the most widespread vegetation species in the ice-free environments in Antarctica (Longton, 1988; Øvstedal and Lewis-Smith, 2001; Seimour et al., 2007).

Secondly, grass formation occupies $4.1 \%$ of the total area of the peninsula. This vegetation formation is dominated by the only two endemic phanerogam species in Antarctica: Deschampsia antarctica and Colobanthus quitensis (Cuba et al., 2005; Zúñiga et al., 2009; Vera, 2011; Casanova-Katny and Cavieres, 2012; Vera et al., 2013). Some authors have highlighted the recent expansion in the population of both species on different sites of the AP in connection with the current global warming scenario (Torres-Mellado et al., 2011; Vera, 2011). The same would apply to lichens and mosses, which are among the best-equipped species to rapidly colonise the new ice-free areas (Favero-Longo et al., 2012). This led to the introduction of the idea of landscape greening of many areas of the AP (Convey and Smith, 2006) as a response to the warming recorded between the middle and the end of the 20th century (Turner et al., 2005; Oliva et al., 2017). In relation to the temperature increase registered in previous decades, authors such as Convey and Smith (2006) point out the risks associated with exotic flora entering the ice-free areas of Antarctica. In this context, two species of non-native vascular plants in Antarctica have been identified on King George Island: Juncus bufonius and Poa annua (Olech, 1996; Olech and Chwedorzewska, 2011; Cuba-Díaz et al., 2013). These new exotic species have not been identified in Elephant Point. Alternatively, moss formation is the least extended type of vegetation in this peninsula, occupying predominantly $1.4 \%$ of the ice-free terrain forming Elephant Point.

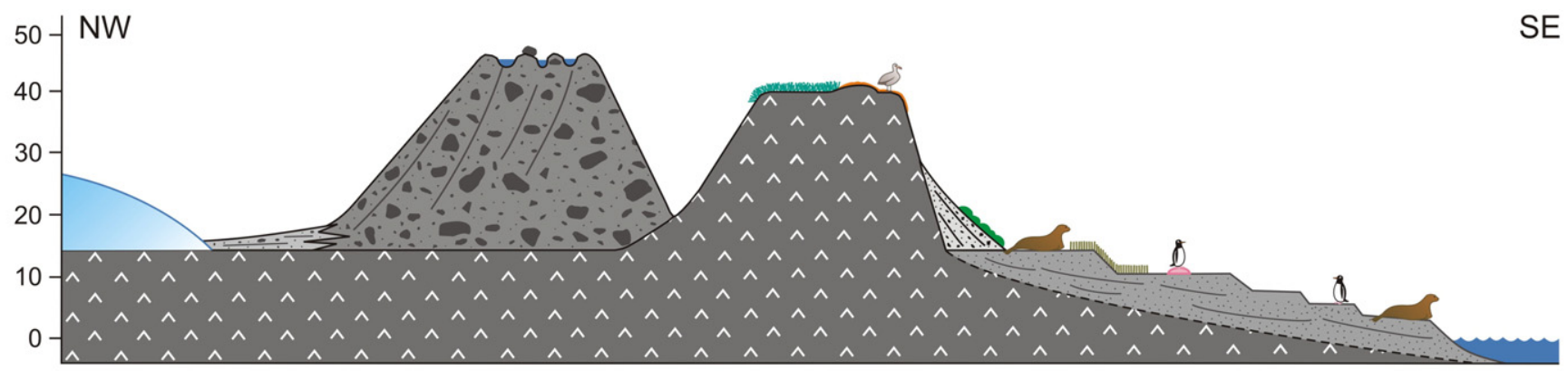

m a.s.l.
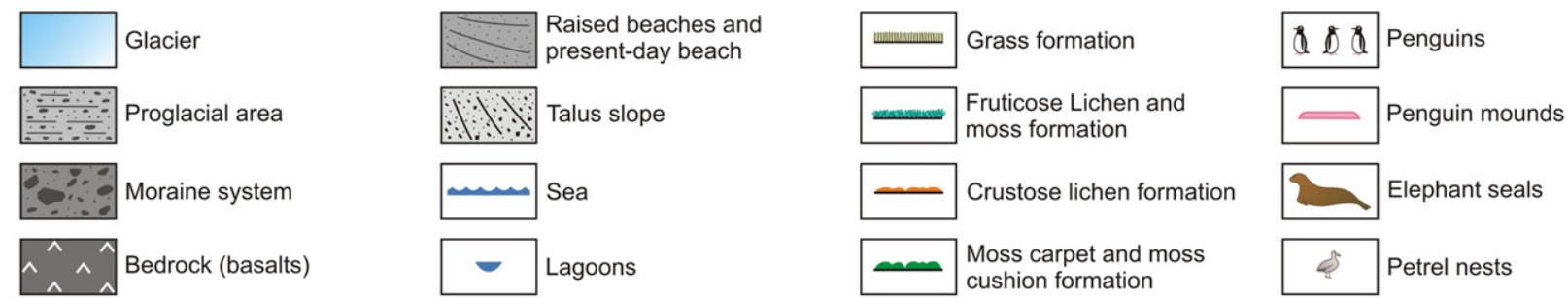

Fig. 3. Transept from the glacier to the present-day beach with the distribution of vegetation formations and their relationships with wildlife and the geomorphological setting. 

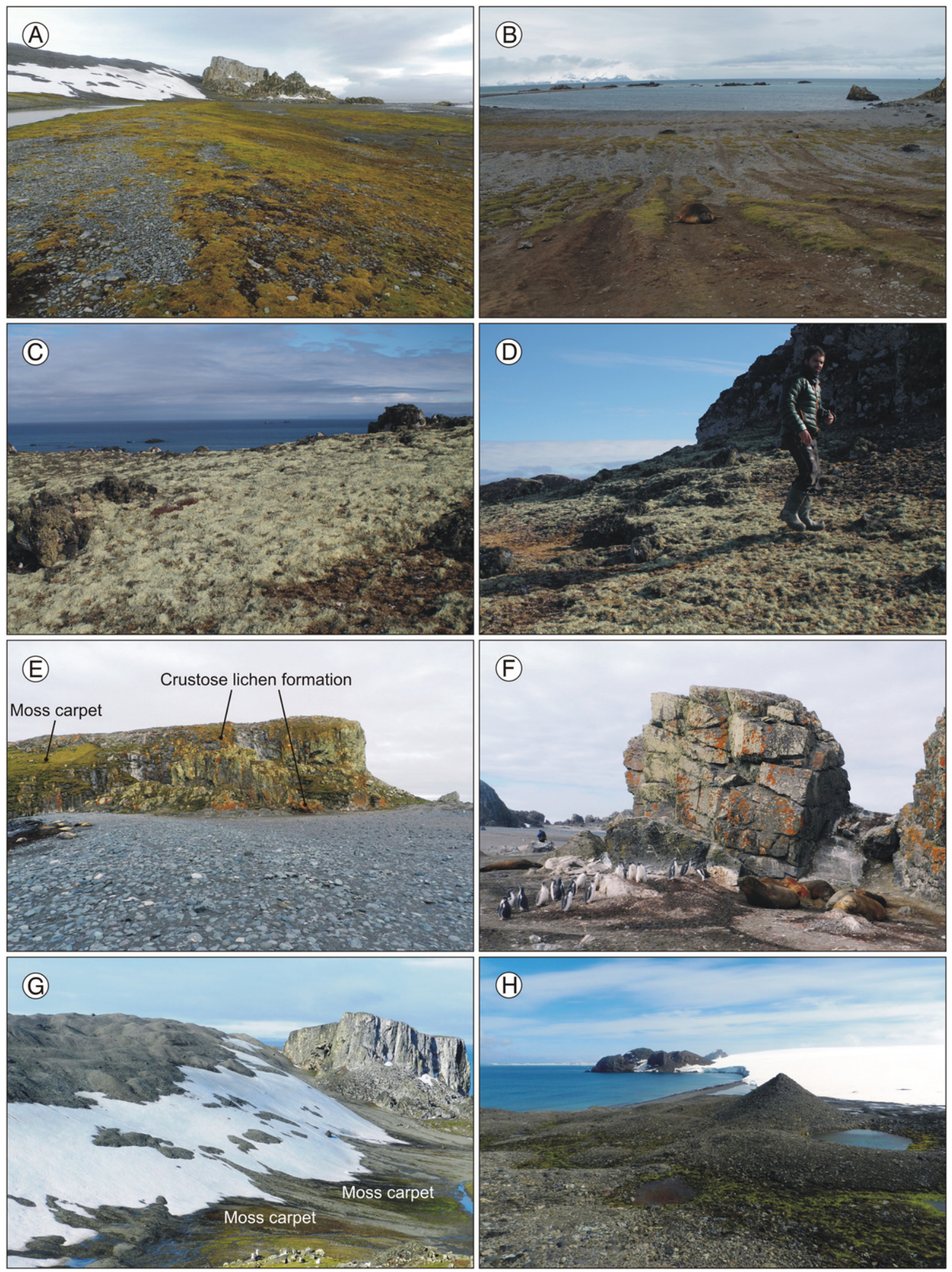

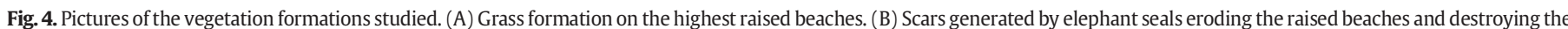

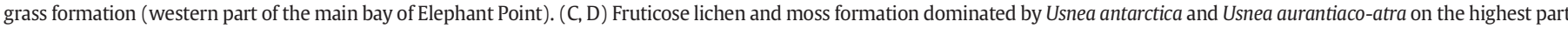

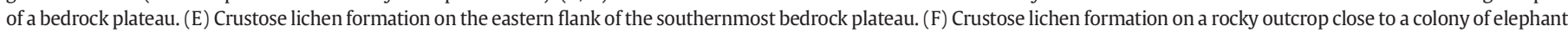
seals and a penguin rookery. $(\mathrm{G})$ Mosses on the higher levels of the raised beaches in the main bay. $(\mathrm{H})$ Mosses on near poorly-drained areas located in the top of the moraine.

The four vegetation formations identified in Elephant Point are primarily distributed on the basaltic bedrock plateaus, which constitute the most widely colonised geomorphological unit, and secondarily on the series of Holocene raised beaches developed in the southern side of the peninsula (Figs. 2 and 5A). So much so that both units combined account for $99.1 \%$ of the area colonised by vegetation in the peninsula.
For its part, the polygenic moraine system deposited by the Rotch Dome glacier, which crosses the peninsula from east to west, as well as the proglacial area generated since 1956 , on which date the Rotch Dome glacier still sat in contact with the moraine (Oliva and Ruiz-Fernández, 2015, 2016), are practically void of vegetation, except for some species of mosses forming small cushions (and some isolated 

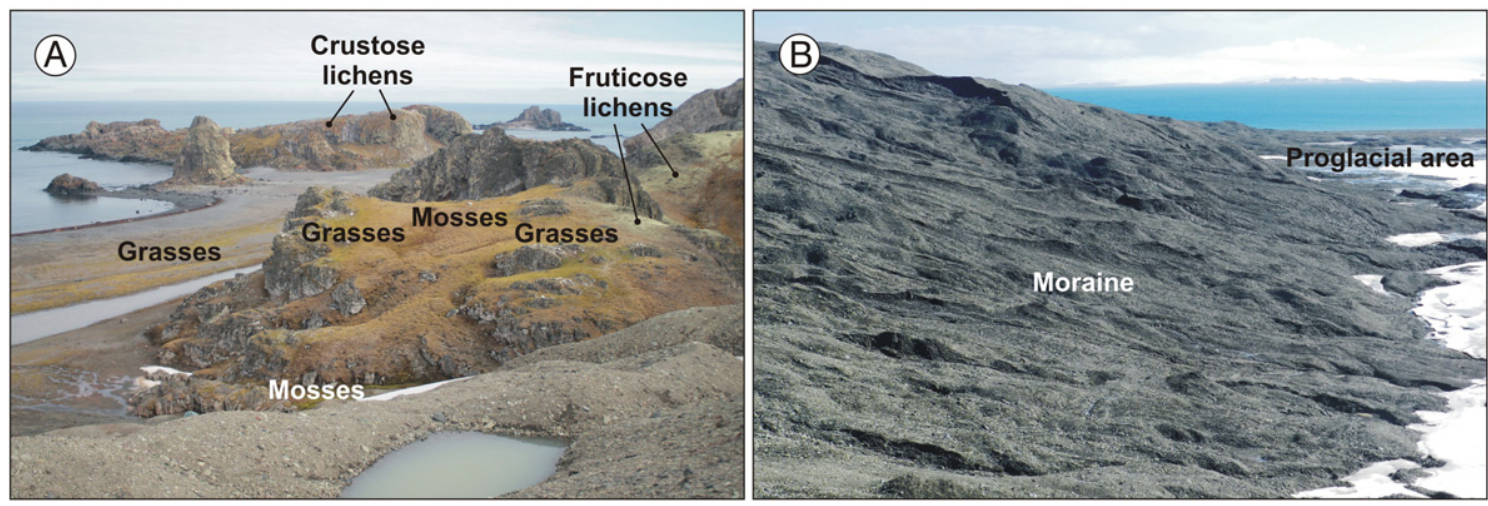

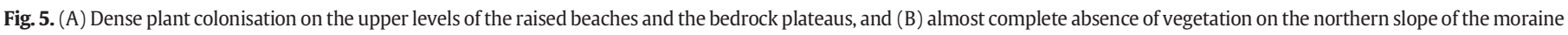
and the proglacial area, both dominated by paraglacial processes.

lichens that are impossible to represent on a map), which cover a mere $0.2 \%$ of the proglacial area and $0.4 \%$ of the moraine system, which only represents $6.4 \%$ of the total area occupied by moss formation in the peninsula (Figs. 2 and 5B). Vegetation colonisation, except for the abovementioned mosses, is hindered by the short period of time passed, the intense slope activity associated with the paraglacial dynamics currently developing in both areas (Oliva and Ruiz-Fernández, 2015, 2016), and the significant water saturation of the sediments integrating the moraine and the proglacial area. The fact that vegetation develops almost exclusively in the two oldest geomorphological units of the peninsula, certifies that one of the key factors to explain vegetation colonisation in the ice-free areas of Antarctica is the time passed since their deglaciation. In fact, the space colonised by vegetation in the deglaciated terrain after 1956 comprises only $0.3 \%$ of the total vegetated area of the peninsula.

Nevertheless, other very important local factors must be taken into consideration, such as wind exposition, degree of soil development, higher or lower soil humidity, geomorphological dynamics, duration of the snow cover and the presence or absence of wildlife (Serrano, 2003). Therefore, the largest patches of grass formation are located on the raised beaches in the main bay of Elephant Point, sheltered from strong westerly winds, and secondarily in the easternmost bay, likewise protected from the winds (Fig. 2). These two areas combined represent $90.8 \%$ of the terrain colonised by this vegetation formation. Conversely, the raised beaches of the western side, constantly swept by the wind, are void of this type of vegetation. In this respect, Vera (2011) points out that the abundance of Deschampsia antarctica and Colobanthus quitensis around the scientific base Juan Carlos I, on Livingston Island (Fig. 1), decreases with altitude, especially with west orientation, as it is less protected from the wind. This could account for the lower abundance of grass formation on bedrock plateaus (concentrating only $9.2 \%$ of this formation), as these plateaus are considerably more exposed to strong winds. On the other hand, as has been detected in the floristic surveys conducted in Elephant Point, Vera (2011) emphasises that the Deschampsia antarctica is much more abundant than the Colobanthus quitensis, due to the higher ecological breadth of the former.

Up to $29.6 \%$ of the bedrock plateaus ( 5.90 ha) has been colonised by the two vegetation formations composed mainly of lichens (Fig. 2). This vegetation is formed by taxons that can survive in more extreme climatic conditions than those of the two previous vascular plants. In this sense, the different species integrating the Usnea type have greater ecological breadth (Schroeter et al., 1995; Vieira et al., 2014), and they can be found either in environments exposed to or sheltered from strong winds, both in in humid and dry areas (Øvstedal and Lewis-Smith, 2001). Snow redistribution by wind is favoured by the prominence and flat top surface of these plateaus. Thus, these areas will lose their snow first, thereby allowing the development of this type of cryptogamic vegetation. On the contrary, as Vieira et al. (2014) has noted in King
George Island, the snow persists longer in the concave depressions and, therefore, the abovementioned cryptogam formations, mainly integrated by species of the Usnea type, are either less abundant or completely absent.

Areas with higher edaphic humidity are mainly covered by moss formation, as has been verified in the nearby Byers Peninsula (Correia et al., 2016; Ruiz-Fernández and Oliva, 2016). However, a clear gradation of species can be observed even in this formation, depending on the higher or lower water saturation. Species such as Sanionia uncinata, Warnstorfia laculosa or Warnstorfia sarmentosa predominate in areas with soils frequently flooded, such as lagoon edges and the alluvial fans situated at the foot of the south flank of the moraine, as they are abundantly supplied with water by permanent snowfields. In this environment they may occasionally form relatively large carpets. Conversely, humid but better drained sites host mosses such as Andreaea gainii, Andreaea depressinervis, Pohlia nutans, Polytrichastrum alpinum and Polytrichum piliferum (Furmanczyk and Ochyra, 1982).

As mentioned above, another determinant factor is the degree of soil development, heavily affected by the cryogenic dynamics (Moura et al., 2012). Soils become thicker and have more organic content on the highest raised beaches. Ornithogenic soils are formed due to the abundance of birdlife (e.g. the presence of rookeries of gentoo penguins; Fig. 2). The abundance of colonies of pinniped such as elephant seals also guarantees a substantial provision of nitrogen and other nutrients (Fig. 2). Similarly, particles washed away and transported by melted snow water from adjacent slopes contribute to the accumulation of nutrients on raised beaches, due to their horizontality. On these richer soils the most common vegetation is grass formation dominated by Deschampsia antarctica. Interestingly, most of the factors determining the absence or presence of vegetation in the Maritime Antarctica also control soil formation (e.g. topography, bedrock, climate, organisms, and time; Otero et al., 2013).

Besides a penguin rookery, there are several colonies of southern giant petrels in various areas of the bedrock plateaus. Diverse communities of ornithocoprophilous lichens grow on rocky outcrops around these colonies In general, lichen-dominated formations cover $29.6 \%$ of the surface of bedrock plateaus ( 5.9 ha), thus becoming the most common type of vegetation formation in the peninsula. The ornithogenic soils present on rocky outcrops also foster the existence of thick moss cushions. Moss formation constitutes the second most abundant vegetation type in this geomorphological unit, colonising 5.8\% of its area (1.2 ha). On the other hand, we must note the important role played by birds, very abundant on the bedrock plateaus, in the dissemination of vegetation toward new areas, together with the role played by the wind and the water (Vera, 2011).

Lastly, geomorphological dynamics also conditions vegetation distribution. The geomorphic action of processes such as debris flows, mudflows, landslides, rock avalanches, stream incision, cryoturbation, 
nivation, etc. prevent and/or hinder the vegetation colonisation of the superficial formations. However, the presence of patterned ground features, either inactive or showing low activity, such as stone sorted-circles and mudboils that rely on the accumulation of fine materials in its centre, favour vegetation colonisation by lichens in dry and windy sites, and by mosses in flooded areas (Serrano, 2003).

\section{Conclusions}

The vegetation of the ice-free area in the Elephant Point peninsula develops almost exclusively in the two oldest geomorphological units, while the territory colonised in the deglaciated area since 1956 comprises a mere $0.3 \%$ of the total vegetated area. This verifies that the time passed since the deglaciation is a key factor to explain vegetation colonisation in the ice-free areas of Antarctica. Nevertheless, this time lapse may vary with regard to diverse factors such as height, wind exposition, humidity, geomorphological dynamics, soil development, and the presence or absence of wildlife.

In the first place, soils in the recently deglaciated areas are highly unstable. An intense paraglacial activity is underway, with continuous sediment removal both in the proglacial area and in the moraine system. Consequently, the attenuation of these processes is necessary for sediment stabilisation and the development of vegetation colonisation. At the same time, the permafrost is widely distributed in these sites, and during the Antarctic summer the active layer is oversaturated with water, which constitutes a limiting factor in itself for specific vegetation species. However, certain moss species benefit from the high humidity in the soil, and therefore, alongside some disperse lichens, they constitute the only vegetation formation capable to colonise these two geomorphological units, yet thinly (only $0.6 \%$ of their area).

Besides, various topographic factors favour some vegetation species and hinder the proliferation of others, and consequently they become an essential regulatory factor in vegetation distribution. Higher soils have lower levels of humidity in comparison with other areas, due to the drying action of strong winds and the lack of nutrient contribution from higher geomorphological units. Likewise, vegetation is allowed a longer vegetating period on flat surface areas, fostered by the early removal of the snow cover (also due to the sweeping effect produced by the intense winds), and the lack of important erosion processes. As a consequence, bedrock plateaus become the areas with the highest degree of colonisation in the peninsula. Vegetation formations dominated by lichens are completely restricted to the bedrock plateaus and the rocky outcrops but, as a whole, they constitute the most extended formation in Elephant Point, occupying 5.1\% of this ice-free terrain.

Conversely, raised beaches less exposed to winds, contain the widest area of grass formation. The greater degree of soil development in these environments, due to their flat topography and the particles transported from adjacent slopes, along with the presence of extra nutrients provided by animal detritus, account for the fact that $90.8 \%$ of the area colonised by this formation may be found on raised beaches.

In sum, the spatial distribution pattern of vegetation in the Elephant Point peninsula is clearly conditioned by the retreating process of the Rotch Dome glacier, showing the time as a key factor. Other important factors that explain the distribution of vegetation in this peninsula (in many cases related or dependent on the former) are the climate (especially wind exposition), duration of the snow cover, geomorphology, soils (degree of development, higher or lower humidity) and presence or absence of wildlife. Processes such as paraglacial activity and oversaturation of water play a decisive role in the recent processes of vegetation colonisation. This aspect becomes especially important if we consider the significant number of recently deglaciated areas in the SSI in particular, and in Maritime Antarctica in general.

\section{Acknowledgements}

This research has been funded by the project CTM2016-77878-P. The Antarctic campaign of 2014 was supported by the Portuguese Polar Programme (PROPOLAR) and the Fundação para a Ciência e a Tecnologia of Portugal. The authors wish to thank the Brazilian Antarctic Programme and the Chilean National Antarctic Programme for their logistical support during the fieldwork. Marc Oliva also thanks the AXA Research Fund for funding his Antarctic research, and Cristina GarcíaHernández thanks the FPU programme of the Spanish Ministry of Education, Culture and Sport, for funding her doctoral research contract (grant number MECD-15-FPU14/01279).

\section{References}

Bañón, M., Justel, A., Velázquez, D., Quesada, A., 2013. Regional weather survey on Byers Peninsula, Livingston Island, South Shetland Islands, Antarctica. Antarct. Sci. 25 (2), 146-156.

Bentley, M.J., Hodgson, D.A., Smith, J.A., O Cofaigh, C., Domack, E.W., Larter, R.D., Roberts, S.J., Brachfeld, S., Leventer, A., Hjort, C., Hillenbrand, C.D., Evans, J., 2009. Mechanisms of Holocene paleoenvironmental change in the Antarctic Peninsula region. The Holocene 19, 51-69.

Casanova-Katny, M.A., Cavieres, L.A., 2012. Antarctic moss carpets facilitate growth of Deschampsia antarctica but not its survival. Polar Biol. 35, 1869-1878.

Convey, P., Smith, R.I.L., 2006. Responses of terrestrial Antarctic ecosystems to climate change. Plant Ecol. 182 (1), 1-10.

Correia, A., Oliva, M., Ruiz-Fernández, J., 2016. Evaluation of frozen ground conditions along a coastal topographic gradient at Byers Peninsula (Livingston Island, Antarctica) by geophysical and geoecological methods. Catena. http://dx.doi.org/10.1016/j. catena.2016.08.006.

Cuba, M., Gutiérrez-Moraga, A., Butendieck, B., Gidekel, M., 2005. Micropropagation of Deschampsia antárctica - a frost-resistant Antarctic plant. Antarct. Sci. 17 (1), 69-70.

Cuba-Díaz, M., Troncoso, J.M., Cordero, C., Finot, V.L., Rondanelli-Reyes, M., 2013. Juncus bufonius, a new non-native vascular plant in King George Island, South Shetland Islands. Antarct. Sci. 25 (3), 385-386.

Favero-Longo, S.E., Worland, M.R., Convey, P., Smith, R.I.L., Piervittori, R., Guglielmin, M. Cannone, N., 2012. Primary succession of lichen and bryophyte communities following glacial recession on Signy Island, South Orkney Islands, Maritime Antarctic. Antarct. Sci. 24, 323-336.

Furmanczyk, K., Ochyra, R., 1982. Plant communities of the Admiralty Bay region (King George Island, South Shetland Islands, Antarctic). Pol. Polar Res. 3 (1-2), 25-39.

Harvey, K.R., Hill, G.J.E., 2001. Vegetation mapping of a tropical freshwater swamp in the Northern Territory, Australia: a comparison of aerial photography, Landsat TM and SPOT satellite imagery. Int. J. Remote Sens. 22, 2911-2925.

Ingólfsson, O., Hjort, C., Berkman, P.A., Björck, S., Colhoun, E., Goodwin, I.D., Hall, B.L. Hirakawa, K., Melles, M., Prentice, M.L., 1998. Antarctic glacial history since the last glacial maximum: an overview of the record on land. Antarct. Sci. 10 (3), 326-344.

Kokaly, R.F., Despain, D.G., Clark, R.N., Livo, E., 2003. Mapping vegetation in Yellowstone National Park using spectral feature analysis of AVIRIS data. Remote Sens. Environ. 84, 437-456.

Lewis, R.I., 1995. Colonization by lichens and the development of lichen-dominated communities in the maritime Antarctic. Lichenologist 27 (6), 473-483.

Longton, R.E., 1988. The Biology of Polar Bryophytes and Lichens. Cambridge University Press, Cambridge (391 pp.).

Moura, P.A., Francelino, M.R., Schaefer, C.E.G.R., Simas, F.N.B., de Mendonça, B., 2012. Distribution and characterization of soils and landform relationships in Byers Peninsula, Livingston Island, Maritime Antarctica. Geomorphology 155-156, 45-54.

Newsham, K.K., 2010. The biology and ecology of the liverwort Cephaloziella varians in Antarctica. Antarct. Sci. 22 (2), 131-143.

Ó Cofaigh, C., Davies, B.J., Livingstone, S.J., Smith, J.A., Johnson, J.S., Hocking, E.P., Hodgson, D.A., Anderson, J.B., Bentley, M.J., Canals, M., Domack, E., Dowdeswell, J.A., Evans, J., Glasser, N.F., Hillenbrand, C.D., Larter, R.D., Roberts, S.J., Simms, A.R., 2014. Reconstruction of ice-sheet changes in the Antarctic Peninsula since the last glacial maximum. Quat. Sci. Rev. 100, 87-110.

Olech, M., 1996. Human impact on terrestrial ecosystems in west Antarctica. Proceedings of the NIPR Symposium on Polar Biology. Vol. 9, pp. 299-306.

Olech, M., Chwedorzewska, K.J., 2011. The first appearance and establishment of an alien vascular plant in natural habitats on the forefield of a retreating glacier in Antarctica. Antarct. Sci. 23, 153-154.

Oliva, M., Ruiz-Fernández, J., 2015. Coupling patterns between para-glacial and permafrost degradation responses in Antarctica. Earth Surf. Process. Landf. 40, 1227-1238.

Oliva, M., Ruiz-Fernández, J., 2016. Geomorphological processes and frozen ground conditions in Elephant Point (Livingston island, South Shetland Islands, Antarctica). Geomorphology http://dx.doi.org/10.1016/j.geomorph.2016.01.020.

Oliva, M., Ruiz-Fernández, J., Zarankin, A., Casanova-Katny, A., Nofre, J., 2016. Geoecology and historical heritage in the ice-free area of elephant point (Antarctica). Proposal for future environmental protection. Geoheritage. http://dx.doi.org/10.1007/s12371016-0184-1.

Oliva, M., Navarro, F.J., Hrbáček, F., Hernández, A., Nývlt, D., Pereira, P., Ruiz-Fernández, J., Trigo, R., 2017. Recent regional cooling of the Antarctic Peninsula and its impacts on the cryosphere. Sci. Total Environ. 580, 210-223. 
Otero, X.L., Fernández, S., de Pablo, M.A., Nizoli, E.C., Quesada, A., 2013. Plant communities as a key factor in biogeochemical processes involving micronutrients ( $\mathrm{Fe}, \mathrm{Mn}, \mathrm{Co}$, and $\mathrm{Cu}$ ) in Antarctic soils (Byers Peninsula, maritime Antarctica). Geoderma 195-196, $145-154$.

Øvstedal, D.O., Lewis-Smith, R.I., 2001. Lichens of Antarctica and South Georgia. A Guide to their Identification and Ecology. Cambridge University Press, Cambridge (411 pp.).

Remias, D., Wastian, H., Lütz, C., Leya, T., 2013. Insights into the biology and phylogeny of Chloromonas polyptera (Chlorophyta), an alga causing orange snow in Maritime Antarctica. Antarct. Sci. 25 (5), 648-656.

Ruiz-Fernández, J., Oliva, M., 2016. Relative paleoenvironmental adjustments following deglaciation of the Byers Peninsula (Livingston Island, Antarctica). Arct. Antarct. Alp. Res. 48 (2), 345-359.

Sancho, L.G., Valladares, F., 1993. Lichen colonization of recent moraines on Livingston Island (South Shetland I., Antarctica). Polar Biol. 13:227. http://dx.doi.org/10.1007/ BF00238757.

Schroeter, B., Heitland, W., Olech, M., Kappen, L., 1995. Ecophysiological investigations of Usnea antarctica in the maritime Antarctic I. Annual microclimatic conditions and potential primary production. Antarct. Sci. 7, 251-260.

Seimour, F.A., Crittenden, P.D., Wirtz, N., Øvstedal, D.O., Dyer, P.S., Thorsten, H., 2007. Phylogenetic and morphological analysis of Antarctic lichen-forming Usnea species in the group Neuropogon. Antarct. Sci. 19 (1), 71-82.

Serrano, E., 2003. Paisaje y pisos geoecológicos en las áreas libres de hielo de la Antártida Marítima (Islas Shetland del Sur). Boletín de la AGE 35, 5-32.

Serrano, E., 2008. Islas de hielo. Naturaleza, presencia humana y paisaje en las Islas Shetland del Sur, Antártida. Universidad de Valladolid, Valladolid (248 pp.)

Toro, M., Camacho, A., Rochera, C., Rico, E., Bañó, M., Fernández-Valiente, E., Mar-co, E., Justel, A., Avendano, M.C., Ariosa, Y., Vincent, W.F., Quesada, A., 2007. Limnological characteristics of freshwater ecosystems of Byers Peninsula, Livingston Island, in Maritime Antarctica. Polar Biol. 30 (5), 635-649.
Torres-Mellado, G.A., Jaña, R., Casanova-Katny, M.A., 2011. Antactic hairgrass expansion in the South Shetland archipiélago and Antarctic Peninsula revisited. Polar Biol. 34, $1679-1688$.

Turner, J., Colwell, S.R., Marshall, G.J., Lachlan-Cope, T.A., Carleton, A.M., Jones, P.D., Lagun, V., Reid, P.A., Iagovkina, S., 2005. Antarctic climate change during last 50 years. Int. J. Climatol. 25, 279-294.

Vera, M.L., 2011. Colonization and demographic structure of Deschampsia antarctica and Colobanthus quitensis along an altitudinal gradient on Livingston Island, South Shetland Islands, Antarctica. Polar Res. 30:7146. http://dx.doi.org/10.3402/polar.v30i0. 7146.

Vera, M.L., Fernández-Teruel, T., Quesada, A., 2013. Distribution and reproductive capacity of Deschampsia antarctica and Colobanthus quitensis on Byers Peninsu-la, Livingston Island, South Shetland Islands, Antarctica. Antarct. Sci. 25 (2), 292-302.

Victoria, F. de C., de Albuquerque, M.P., Pereira, A.B., Simas, F.N.B., Spielmann, A.A., Schaefer, C.E.G.R., 2013. Characterization and mapping of plant communities at Hennequin Point, King George Island, Antarctica. Polar Res. 32:19261. http://dx.doi. org/10.3402/polar.v32i0.19261.

Vieira, G., Mora, C., Pina, P., Schaefer, C., 2014. A proxy for snow cover and winter ground surface cooling: mapping Usnea sp. communities using high resolution re-mote sensing imagery (Maritime Antarctica). Geomorphology 225, 69-75.

Xie, Y., Sha, Z., Yu, M., 2008. Remote sensing imagery in vegetation mapping: a review. J. Plant Ecol. 1, 9-23.

Zarankin, A., Senatore, M.X., 2005. Archaeology in Antarctica: nineteenth-century capitalism expansion strategies. Int. J. Hist. Archaeol. 9 (1), 43-56.

Zúñiga, G.E., Zamora, P., Ortega, M., Obrecht, A., 2009. Micropropagation of Antarctic Colobanthus quitensis. Antarct. Sci. 21 (2), 149-150. 